\title{
HAK-HAK DAN PERLINDUNGAN HUKUM TERHADAP PEMEGANG SAHAM MINORITAS AKIBAT MERGER PADA BANK SYARIAH INDONESIA
}

\author{
R Dinan Rayan Makhfirah
}

Fakultas Hukum Universitas Indonesia (UI) Jakarta, Indonesia

Email: dinanrayan16@gmail.com

\begin{tabular}{l}
\hline INFO ARTIKEL \\
\hline Diterima \\
28 Desember 2021 \\
Direvisi \\
30 Desember 2021 \\
Disetujui \\
1 Januari 2022 \\
\hline Kata Kunci: \\
Hak-Hak; \\
Perlindungan \\
Hukum; Pemegang \\
Saham Minoritas; \\
Merger; Bank \\
Syariah Indonesia
\end{tabular}

\section{ABSTRAK}

Merger adalah salah satu cara yang dilakukan oleh bank-bank di Indonesia untuk mengembangkan usahanya, menambah modal dan membuat sinergi perbankan yang merupakan strategi bisnis di masa yang akan datang. Tindakan tersebut pastinya diambil melalui Rapat Umum Pemegang Saham (RUPS). Peserta Rapat Umum Pemegang Saham (RUPS) yaitu para Pemegang Saham, Komisaris dan Direksi. Dalam kenyataannya didalam suatu perusahaan yang sudah berbentuk perseroan maka pemegang saham akan terbagi kedalam dua jenis apabila dilihat dari komposisi kepemilikan sahamnya yaitu pemegang saham mayoritas dan pemegang saham minoritas. Kepentingan antara pemegang saham dominan atau mayoritas dan pemegang saham minoritas dalam menjalankan usaha perusahaan seringkali tidak sejalan satu sama lain. Apabila dalam Rapat Umum Pemegang Saham (RUPS) terdapat perbedaan pendapat antara pemegang saham mayoritas dengan pemegang saham minortitas dan mekasnisme pengambilan keputusan itu suara terbesar berdasarkan saham terbanyak maka pemegang saham minoritas ini akan selalu kalah dibandingkan pemegang saham mayoritas. Hal tersebut sangat merugikan pemegang saham minoritas dikarenakan tidak tercapainya maksud dan tujuan mereka karena dikalahkan oleh sistem pengambilan suara berdasarkan saham terbanyk. Oleh karena itu pemegang saham minoritas perlu untuk dilindungi. Jenis penelitian yang digunakan dalam penelitian ini adalah yuridis normatif. Sumber data yang digunakan adalah data sekunder yang terdiri dari bahan hukum primer, sekunder, dan tersier. Teknik pengumpulan data yang digunakan dalam penelitian ini adalah penelitian kepustakaan. Hak-hak pemegang saham minoritas yaitu hak perseorangan (personal right), hak penilaian (appraisal right), hak yang didahulukan (pre-empitive right), hak angket (enquette right), dan hak derivatif. Ada dua bentuk perlindungan hukum yaitu bersifat preventif dan refresif. Bentuk perlindungan preventif, yaitu perlindungan hukum yang diberikan kepada pemegang saham minoritas khususnya PT terbuka. Perlindungan preventif adalah perlindungan untuk mencegah adanya sengketa. Perlindungan preventif ini, subjek hukum diberikan kesempatan untuk mengajukan keberatan atau pendapatnya sebelum suatu keputusan pemerintah mendapat bentuk yang definitif. Sedangkan Perlindungan hukum represif bertujuan untuk menyelesaikan sengketa yang terjadi di masyarakat agar tercapai penyelesaian yang adil. Penanganan perlindungan hukum oleh pengadilan umum dan peradilan administrasi di Indonesia termasuk kategori perlindungan hukum ini.

\begin{tabular}{ll}
\hline How to cite: & Makhfirah, R. D. R. (2022). Hak-Hak dan Perlindungan Hukum Terhadap Pemegang Saham \\
& Minoritas Akibat Merger pada Bank Syariah Indonesia, Jurnal Syntax Transformation, 3(1). \\
& https://doi.org/10.46799/jst.v3i1.500 \\
E-ISSN: & $2721-2769$ \\
Published by: & Ridwan Institute
\end{tabular}




\begin{tabular}{|c|c|}
\hline $\begin{array}{l}\text { Keywords: } \\
\text { Rights; } \quad \text { Legal } \\
\text { Protection; } \\
\text { Minority } \\
\text { Shareholders; } \\
\text { Merger; Indonesian } \\
\text { Sharia Bank }\end{array}$ & 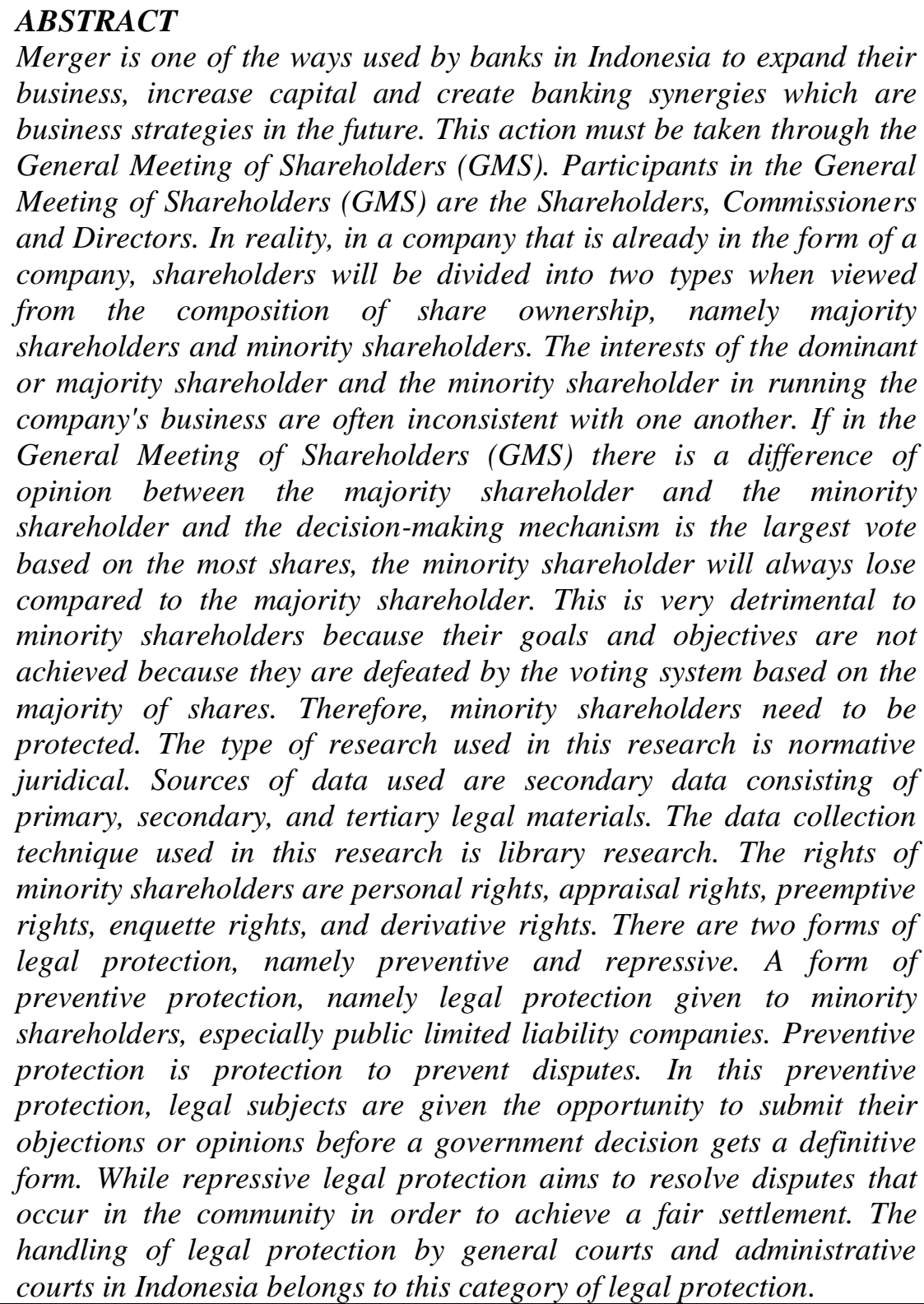 \\
\hline
\end{tabular}

\section{Pendahuluan}

Secara general terdapat dua cara pertumbuhan perusahaan, yang pertama menurut pada perusahaan itu sendiri (internal) contohnya pengembangan kapasitas produksi (expand capacity) melalui penambahan pekerja atau memperbesar faktor produksi lainnya. Pilihan lainnya adalah pertumbuhan dari luar (external) melalui merger dan akuisisi (M\&A) yang menggabungkan kedua faktor produksi dari masing-masing perusahaan (Ebner, 2012). Kedua cara tersebut memiliki kekuatan dan kelemahan masing-masing. Merger atau Akuisisi (M\&A) perusahaan yang beroperasi dengan karyawan dan teknologi, dan jaminan bahwa produk mereka akan diterima oleh pasar, akan menghemat lebih banyak waktu daripada pertumbuhan internal perusahaan. Selain itu, perusahaan yang melakukan merger dan akuisisi dapat memperoleh teknologi untuk strategi pertumbuhan mereka, tetapi juga dibatasi oleh persyaratan paten, atau perusahaan harus memperoleh sumber daya manusia yang tidak mudah tersedia di pasar, 
dan mereka umumnya tidak dapat mencapai tujuan perusahaan secara internal.

Namun, merger dan akuisisi lebih disukai oleh perusahaan dengan potensi keuangan yang kuat (strong financial). Para pelaku bisnis ini lebih memilih menghemat waktu dengan tidak melakukan riset pasar dan pengujian suatu produk daripada mencari produk baru yang dapat menghasilkan pangsa pasar baru. Sekarang dunia sedang menuju ke era merger dan akuisisi (M\&A), ada banyak perusahaan global dengan potensi keuangan tinggi (strong financial) yang telah berpaling dari memulai bisnis baru dari awal dan lebih memilih merger dan akuisisi. Entitas bisnis yang kuat secara finansial akan menggunakan dalih merger dan akuisisi sebagai tindakan pengendalian pasar.

Merger, akuisisi serta konsolidasi yang merupakan resapan berasal bahasa inggris mempunyai pengertian menjadi penggabungan, konsolidasi menjadi peleburan serta akusisi menjadi pengambilalihan. Merger, akuisisi serta konsolidasi (untuk kemudian penyebutan "merger dan akuisisi" serta/atau "konsolidasi" disingkat menjadi "Merger". Para pelaku usaha yang melakukan merger merupakan pelaku usaha yang independen yang dilakukan secara menyeluruh dan permanen (Sufrin \& Jones, 2001). Secara teori, tindakan merger dapat menciptakan efisiensi dari berbagai aspek (Lubis \& Sirait, 2009). Efisiensi tercipta karena perusahaan hasil Merger akan dapat mengeksploitasi skala ekonomi (economic of scale) dalam proses produksi. Skala ekonomi menjadi penting bila di dalam suatu pasar, biaya produksi yang diperlukan akan sangat tinggi dibandikan dengann besarnya pasar Merger juga akan meningkatkan efisiensi melalui marketing atau sentralisasi research and development karena dapat melayani jumlah unit yang lebih besar.

Merger mejadi suatu batuan bagi pelaku usaha untuk keluar dari permasalah financial sepertinya kesulitan untuk meneruskan usahanya atau dalam keadaan pailit maupun likuidasi. Permasalahan financial yang dimaksud diatas tidak hanya dikarenkan alasan internal pelaku usaha tersebut namun juga dapat disebabkan adanya keharusan pemenuhan peraturan pemerintah, sebagai contoh adalah program Arsitektur Perbankan Indonesia yang mengaharuskan adanya peningkatan rasio cadangan bank umum. Tindakan ini memaksa perusahaan komersial di sektor perbankan untuk mengambil salah satu dari 2 (dua) langkah, yaitu menyuntikkan lebih banyak uang atau melakukan penggabungan.

Merger merupakan salah satu strategi usaha ke depan yang bertujuan memperkuat permodalan perusahaan atau untuk tujuan kepemilikan perusahaan dengan penguasaan mayoritas saham (Budianto, 2004). Merger dalam sektor perbankan diatur pemerintah yang dituangkan dalam Peraturan Pemerintah Republik Indonesia Nomor 28 Tahun 1999 Tentang Merger, Konsolidasi dan Akuisisi Bank, menjelaskan bahwa "Merger adalah penggabungan dari dua bank atau lebih dengan cara tetap mempertahankan berdirinya salah satu bank dan membubarkan bank-bank lainnya tanpa menglikuidasi terlebih dahulu". Merger adalah salah satu cara yang dilakukan oleh bank-bank di Indonesia untuk mengembangkan usahanya, menambah modal dan membuat sinergi perbankan yang merupakan strategi bisnis di masa yang akan datang. Tindakan tersebut pastinya diambil melalui Rapat Umum Pemegang Saham (RUPS).

Peserta Rapat Umum Pemegang Saham (RUPS) yaitu para Pemegang Saham, Komisaris dan Direksi. Dalam kenyataannya didalam suatu perusahaan yang sudah berbentuk perseroan maka pemegang saham akan terbagi kedalam dua jenis apabila dilihat dari komposisi kepemilikan sahamnya yaitu pemegang saham mayoritas dan pemegang saham minoritas. Dalam menjalankan 
kegiatan suatu perusahaan maka pemegang saham mayoritas mampu untuk mempengaruhi hal tersebut, termasuk memiliki perant penting dalam pemberian keputusan untuk melakukan merger suatu perusahaan dalam Rapat Umum Pemegang Saham (RUPS), sedangkan pemegang saham minoritas dalam menjalankan suatu perusahaan tidak memiliki kemampuan untuk mengubah suatu keputusan Rapat Umum Pemegang Saham (RUPS) untuk melakukan merger. Kepentingan antara pemegang saham dominan atau mayoritas dan pemegang saham minoritas dalam menjalankan usaha perusahaan seringkali tidak sejalan satu sama lain.

Minority shareholders atau pemegang saham minoritas sering kali dikesampingkan dalam sebuah perusahaan. Apabila dalam Rapat Umum Pemegang Saham (RUPS) terdapat perbedaan pendapat antara pemegang saham mayoritas dengan pemegang saham minortitas dan mekasnisme pengambilan keputusan itu suara terbesar berdasarkan saham terbanyak maka pemegang saham minoritas ini akan selalu kalah dibandingkan pemegang saham mayoritas. Hal tersebut sangat merugikan pemegang saham minoritas dikarenakan tidak tercapainya maksud dan tujuan mereka karena dikalahkan oleh sistem pengambilan suara berdasarkan saham terbanyk. Oleh karena itu pemegang saham minoritas perlu untuk dilindungi.

Pertimbangan lain pemegang saham minoritas itu harus dilindungi yaitu karena hasil putusan yang didapat dari pemegang saham dominan dalam suatu Rapat Umum Pemegang Saham (RUPS) tidak selamanya adil bagi pemegang saham minoritas, walaupun mekanisme pengambilan keputusan secara mayoritas tersebut adalah yang paling demokratis. Sebab, dengan sistem putusan mayoritas tersebut, bisa saja seorang yang sudah membiayai perusahaan sampai $49 \%$ (empat puluh sembilan persen) dengan memegang saham 49\% (empat puluh sembilan persen) mempunyai kedudukan yang persis sama dalam pemberian suara dengan pemegang saham hanya $2 \%$ (dua persen) saham, dan akan sangat berbeda dengan pemegang saham 52\% ( lima puluh dua persen). Ini menjadi tidak fair (Fuady, 2003). Indonesia telah terjadi merger antara Bank BNI Syariah, Bank BRI Syariah dan Bank Syariah Mandiri menjadi Bank Syariah Indonesia yang mana pemegang sahamnya sepakat melalui RUPS untuk melakukan merger. Kemudian di dalamnya pasti ada pemegang saham mayoritas dan pemegang saham minoritas.

Kondisi seperti itu sangat diperlukan peran teori keadilan yang terdapat dalam Good Corporate Governance untuk memastikan terlindunginya hak-hak pemegang saham minoritas. Melalui adanya Undang-Undang Nomor 40 Tahun 2007 Tentang Perseroan Terbatas menjamin kepentingan pemegang saham minoritas tidak diabaikan oleh pihak lainnya termasuk juga yaitu pihak pemegang saham mayoritas.

Penelitian ini selaras dengan penelitian yang dilakukan oleh (Priandhana et al., 2016) yang mana dalam penelitian sebelumnya membahas mengenai Perlindungan Hukum terhadap Pemegang Saham Minoritas dalam Merger Perbankan Berdasarkan Single Presence Policy (Studi Kasus Pada PT. Bank KEB Indonesia dan PT. Bank Hana Indonesia), sedangkan pada penelitian saat ini adalah hak-hak dan perlindungan hukum terhadap pemegang saham minoritas akibat merger pada bank syariah Indonesia. Keduanya memiliki kesamaan diantaranya ialah membahas mengenai perlindungan hukum terhadap pemegang saham minoritas.

Penelitian yang ditulis oleh (Ramadan, 2021) juga semakin menguatkan penelitian saat ini yang dijadikan sebagai bahan acuan.

\section{Metode Penelitian}

Penulis melakukan penelitian hukum yaitu suatu kegiatan ilmiah, yang didasarkan 
pada metode, sistematika dan pemikiran tertentu, yang bertujuan untuk mempelajari satu atau beberapa gejala hukum tertentu, dengan jalan menganalisanya juga diadakan pemeriksaan yang mendalam terhadap fakta hukum, untuk kemudian mengusahakan suatu pemecahan atas permasalahan yang timbul di dalam gejala hukum yang bersangkutan (Soekanto, 2007).

Metode pendekatan yang digunakan dalam penelitian ini adalah penelitian kepustakaan yang bersifat yuridis normatif, artinya bahwa penelitian ini mengacu kepada norma hukum yang terdapat di dalam peraturan perundang-undangan serta kebiasaan-kebiasaan yang berlaku di masyarakat (Soekanto \& Mamudji, 1979). Adapun pendekatan yang dilakukan adalah pendekatan perundang-undangan (statute approach) dan pendekatan kasus (case study). Dimana pendekatan kasus ini dilakukan dengan cara menelaah terhadap kasus-kasus yang berkaitan dengan isu yang dihadapi yang telah mempunyai kekuatan hukum yang tetap (Marzuki \& SH, 2021).

Data dalam penelitian adalah data-data sekunder, yaitu data yang diperoleh melalui studi kepustakaan, dengan cara membaca, menelaah dan mengutip terhadap berbagai teori, asas dan peraturan yang berhubungan dengan permasalahan penelitian (Soekanto, 2014).

\section{Hasil dan Pembahasan}

1. Hak-Hak Pemegang Saham Minoritas Harmonisasi di antara para pemegang saham sangat penting dalam memajukan dan mengembangkan kegiatan usaha perseroan (Sari et al., 2017). Namun seringkali tidak terhindarkan terjadinya perselisihan antara pemegang saham mayoritas dan pemegang saham minoritas. Dalam rangka perlindungan hukum, UUPT No.40 Tahun 2007 memberikan hak-hak tertentu kepada pemegang saham minoritas agar pemegang saham mayoritas tidak menyalahgunakan kekuasaannya terhadap pemegang saham minoritas (Wilamarta, 2002). Adapun hak-hak pemegang saham minoritas dimaksud adalah sebagai berikut :

a. Hak Perseorangan (Personal Right)

Hak ini menjelaskan bahwa setiap pemegang saham berhak untuk mengajukan gugatan kepada Pengadilan Negeri apabila dirugikan karena tindakan perseroan yang dianggap tidak adil dan tanpa alasan wajar sebagai akibat keputusan RUPS, Direksi, dan/atau Dewan Komisaris. Demikian pula, pemegang saham minoritas atas Namanya sendiri dapat menggugat Direksi atau komisaris, apabila Direksi atau Komisaris tersebut melakukan kesalahan yang merugikan pemegang saham minoritas (Chatamarrasjid, 2004).

b. Hak Penilaian (Appraisal Right)

Pemegang saham minoritas mempunyai hak penilaian, yaitu hak untuk membela kepentingannya dalam hal penilaian harga saham. Pada saat pemegang saham meminta kepada perseroan untuk membeli sahamnya, pemegang saham minoritas dapat menggunakan appraisal right (Hamilton, 1991).

c. Hak yang Didahulukan (Pre-emptive Right)

Perseroan biasanya mengeluarkan saham baru dalam rangka penambahan modal. Hak yang didahulukan adalah hak yang diberikan kepada pemegang saham minoritas untuk dapat didahulukan untuk memiliki atau membeli saham yang ditawarkan oleh perseroan.

d. Hak Angket (Enquette Recht)

Hak angket adalah hak untuk melakukan pemeriksaan atas perseroan. Dalam hal ini pemegang 
saham minoritas diberikan hak oleh undang-undang untuk mengajukan permohonan kepada pengadilan, untuk mengadakan pemeriksaan atas perseroan, jika terdapat dugaan adanya kecurangan-kecurangan atau hal-hal yang disembunyikan oleh direksi, komisaris atau pemegang saham mayoritas.

e. Hak Derivatif

Hak derivative merupakan salah satu hak yang diberikan oleh undangundang kepada pemegang saham minoritas. Secara singkat dapat dikatakan bahwa hak derivatif atau gugatan derivatif adalah hak atau kewenangan pemegang saham minoritas untuk menggugat direksi atau komisaris atas nama perseroan, dalam hal direksi atau komisaris melakukan kesalahan yang menyebabkan kerugian pada perseroan.

2. Perlindungan Hukum Terhadap Pemegang Saham Minoritas Akibat Adanya Merger Pada Bank Syariah Indonesia

$$
\text { Perlindungan hukum bagi }
$$
pemegang saham minoritas menurut Undang-Undang Nomor 40 tahun 2007 tentang Perseroan Terbatas, yaitu dalam anggaran dasar sebuah perusahaan, dapat ditetapkan jenis saham yang berbedabeda, yaitu saham biasa dan saham preferen. Dengan adanya mekanisme saham dalam perseroan ini, maka pemegang saham mayoritas memiliki kewenangan yang lebih besar daripada saham minoritas. Dengan demikian wajar jika pemegang saham mayoritas memiliki kekuasaan yang lebih besar. Namun apabila kewenangan yang dimiliki pemegang saham mayoritas disalahgunakan sehingga menimbulkan kerugian bagi pemegang saham minoritas. Untuk itu Undang-Undang perlu memberikan perlindungan bagi pemegang saham minoritas untuk melindungi kepentingannya.

Menurut Darmaji dan Fakhrudin saham merupakan tanda atau kepemilikan seseorang atau badan dalam suatu perusahaan atau perseroan terbatas (Nasarudin, 2014). Penafsiran ini menunjukkan bahwa bank syariah adalah bank yang menjalankan fungsi intermediasinya berdasarkan prinsip syariah Islam, sehingga diperlukan peraturan untuk mengoperasikan dan mengendalikan bank syariah agar dapat beroperasi sebagaimana dimaksud. Dalam tata cara tersebut, dijauhi praktek-praktek yang dikhawatirkan mengandung unsurunsur riba untuk diisi dengan kegiatankegiatan investasi atas dasar bagi hasil dari pembiayaan perdagangan (Nasarudin, 2014).

Hal-hal yang dikaji dalam perlindungan hukum pemegang saham minoritas adalah mengenai tindakantindakan yang dilakukan pemegang saham mayoritas karena adanya kekuasaan yang dimiliki sehingga terjadilah tindakan memonopoli jalannya perusahaan. Pada perlindungan ini terdapat dua bentuk perlindungan hukum yaitu bersifat preventif dan refresif. Bentuk perlindungan preventif, yaitu perlindungan hukum yang diberikan kepada pemegang saham minoritas khususnya PT terbuka. Perlindungan preventif adalah perlindungan untuk mencegah adanya sengketa. Perlindungan preventif ini, subyek hukum diberikan kesempatan untuk mengajukan keberatan atau pendapatnya sebelum suatu keputusan pemerintah mendapat bentuk yang definitif. Sedangkan Perlindungan hukum represif bertujuan untuk menyelesaikan sengketa yang terjadi di masyarakat agar tercapai penyelesaian yang adil. Penanganan perlindungan 
hukum oleh pengadilan umum dan peradilan administrasi di Indonesia termasuk kategori perlindungan hukum ini.

Berdasarkan perlindungan hukum pemegang saham minoritas ini dapat diketahui secara lebih jelas tindakan apa saja yang dapat membuat pemegang saham minoritas merasa dirugikan sehingga hal-hal ini mencegah terjadinya sengketa yang berujung di pengadilan. Di Indonesia telah diberlakukan ketentuanketentuan yang mengatur tentang pemilikan saham dan kaitannya dengan hak suara dalam RUPS perseroan terbatas. Ketentuan-ketentuan tersebut meliputi KUHD, Undang-undang No.4 Tahun 1971 tentang Perubahan dan penambahan atas ketentuan pasal 54 KUHD, Undang-undang No. 1 tahun 1995 jo Undang-undang No.40 Tahun 2007 tentang Perseroan Terbatas dan Undangundang Republik Indonesia No. 8 tahun 1995 tentang pasar modal yang selanjutnya disebut UUPM.

\section{Kesimpulan}

Hak-Hak pemegang saham minoritas yaitu hak perseorangan (personal right), hak penilaian (appraisal right), hak yang didahulukan (pre-empitive right), hak angket (enquette right), dan hak derivatif. Terdapat dua bentuk perlindungan hukum yaitu bersifat preventif dan refresif. Bentuk perlindungan preventif, yaitu perlindxungan hukum yang diberikan kepada pemegang saham minoritas khususnya PT terbuka. Perlindungan preventif adalah perlindungan untuk mencegah adanya sengketa. Perlindungan preventif ini, subyek hukum diberikan kesempatan untuk mengajukan keberatan atau pendapatnya sebelum suatu keputusan pemerintah mendapat bentuk yang definitif. Sedangkan Perlindungan hukum represif bertujuan untuk menyelesaikan sengketa yang terjadi di masyarakat agar tercapai penyelesaian yang adil. Penanganan perlindungan hukum oleh pengadilan umum dan peradilan administrasi di Indonesia termasuk kategori perlindungan hukum..

\section{BIBLIOGRAFI}

Budianto, A. (2004). Merger Bank di Indonesia (Beserta akibat-akibat hukumnya). Ghalia Indonesia.Google Scholar

Chatamarrasjid. (2004). Penerobosan cadar perseroan dan soal-soal aktual hukum perusahaan. Citra Aditya Bakti. Google Scholar

Ebner, S. (2012). Essays on the Economics of Mergers and Acquisitions. Universität Passau. Google Scholar

Fuady, M. (2003). Perseroan Terbatas Paradigma Baru. Citra Aditya Bakti. Google Scholar

Hamilton, R. W. (1991). The law of corporations in a nutshell (Vol. 3). West Publishing Company. Google Scholar

Lubis, A. F., \& Sirait, N. N. (2009). Hukum persaingan usaha antara teks \& konteks. Jakarta: Komisi Pengawas Persaingan Usaha. Google Scholar

Marzuki, P. M., \& SH, M. S. (2021). Pengantar ilmu hukum. Prenada Media. Google Scholar

Nasarudin, M. I. (2014). Aspek hukum pasar modal Indonesia. Kencana. Google Scholar

Priandhana, A. R., Prananigtyas, P., \& Mahmudah, S. (2016). Perlindungan Hukum terhadap Pemegang Saham Minoritas dalam Merger Perbankan Berdasarkan Single Presence Policy (Studi Kasus Pada PT. Bank KEB Indonesia dan PT. Bank Hana Indonesia). Diponegoro Law Journal, 5(4), 1-20. Google Scholar 
Ramadan, M. R. (2021). Merger Bank Syariah dan Pengembangan UMKM di Indonesia. Jurnal Syntax Transformation, 2(6), 830-842. Google Scholar

Sari, M., Budiono, A. R., \& Widhiyanti, H. N. (2017). Perlindungan Hukum Bagi Pemegang Saham Minoritas yang tidak dilibatkan dalam proses Akuisisi. Yuridika, 32(3), 441-463. Google Scholar

Soekanto, S. (2007). Penelitian hukum normatif: Suatu tinjauan singkat. Google Scholar

Soekanto, S. (2014). Sosiologi suatu pengantar. Google Scholar

Soekanto, S., \& Mamudji, S. (1979). Peranan dan Penggunaan Perpustakaan di Dalam Penelitian Hukum. Jakarta: Pusat Dokumentasi UI. Google Scholar

Sufrin, B. E., \& Jones, A. (2001). EC Competition Law: Text Cases \& Materials. Oxford University Press. Google Scholar

Wilamarta, M. (2002). Hak Pemegang Saham Minoritas Dalam Rangka Good Corporate Governance. Program Pasca Sarjana Fakultas Hukum Universitas Indonesia, Jakarta. Google Scholar

\section{Copyright holder :}

R Dinan Rayan Makhfirah (2022)

First publication right :

Jurnal Syntax Transformation

This article is licensed under: 